\title{
STRATEGI KOMUNIKASI SATUAN LALU LINTAS POLRES BLITAR KOTA MELALUI PROGRAM SAVE OUR STUDENT DALAM UPAYA MENEKAN JUMLAH PELANGGARAN LALU LINTAS PADA PELAJAR
}

\author{
Meita Anisa Saputra \\ meita.anisa.saputra-2015@pasca.unair.ac.id \\ Program Studi Magister kajian Ilmu Kepolisian \\ Sekolah Pascasarjana Universitas Airlangga \\ Jln. Airlangga No.4-6 Surabaya
}

\begin{abstract}
Data from the City Blitar City Police Unit in 2016, as many as 1,799 or 15.9\% of students committed traffic violations, from January to March 2017 as many as 438 or $11.3 \%$ of students committed traffic violations. In addition to violations, 25 or $15.1 \%$ of traffic accidents involving students occurred. The accident caused 68 students to become victims. In 2017 January to March as many as 6 or 12.5\% students were involved in traffic accidents. The accident caused 21 students to become victims. According to the data, it can be seen that the number of traffic violations in Blitar City is dominated by students, both students of junior high schools, senior high schools or vocational high schools. Then the Save Our Student (SOS) program was implemented to reduce the number of traffic offenses for students. The Save Our Student (SOS) Program is a Satlantas Polres Blitar Kota program in collaboration with schools, both Middle School (SMP), Senior High School (SMA) or Vocational High School (SMK) in Blitar City. The Save Our Student (SOS) Program is a program based on Law Number 22 Year 2009 concerning Road Traffic and Transport and the Safety riding program. The Save Our Student (SOS) program is not just a momentary program, but an ongoing program in an effort to reduce the number of traffic violations on students in the City of Blitar. The Blitar City Police Traffic Unit Police in implementing the Save Our Student (SOS) Program needs a communication strategy, where the success rate of a goal will be achieved along with how the communication strategy is carried out in implementing the Save Our Student (SOS) Program. The purpose of the program, which is to reduce the number of traffic violations among students and prevent traffic accidents with fatality fatalities will be achieved.
\end{abstract}

Keywords: Traffic Violations; Save Our Student (SOS); Communication Strategy.

\begin{abstract}
Data Satuan Lalu Lintas Polres Blitar Kota tahun 2016, sebanyak 1.799 atau 15,9 \% pelajar melakukan pelanggaran lalu lintas, tahun 2017 Januari sampai Maret sebanyak 438 atau 11,3\% pelajar melakukan pelanggaran lalu lintas. Selain pelanggaran terjadi 25 atau $15,1 \%$ kecelakaan lalu lintas yang melibatkan pelajar. Kecelakaan tersebut menyebabkan 68 pelajar menjadi korban. Pada tahun 2017 Januari sampai Maret sebanyak 6 atau 12,5\% pelajar terlibat kecelakaan lalu lintas. Kecelakaan menyebabkan 21 pelajar menjadi korban. Menurut data, dapat diketahui angka pelanggaran lalu lintas di Kota Blitar banyak didominasi oleh pelajar baik pelajar Sekolah Menengah Pertama (SMP), Sekolah Menengah Atas (SMA) atau Sekolah Menengah Kejuruan (SMK). Maka diberlakukanlah program Save Our Student (SOS) untuk menekan jumlah pelangaran lalu lintas pada pelajar. Program Save Our Student (SOS) merupakan program Satlantas Polres Blitar Kota bekerja sama dengan pihak sekolah baik Sekolah Menengah Pertama (SMP), Sekolah Menengah Atas (SMA) atau Sekolah Menengah Kejuruan (SMK) di Kota Blitar. Program Save Our Student (SOS) merupakan program yang berdasar pada Undang-Undang Nomor 22 Tahun 2009 tentang Lalu Lintas dan Angkutan Jalan serta program Safety riding. Program Save Our Student (SOS) bukan hanya program sesaat, namun program yang terus berkelanjutan sebagai upaya menekan jumlah pelanggaran lalu lintas pada pelajar di Kota Blitar. Polisi Satuan Lalu Lintas Polres Blitar Kota dalam melaksanakan Program Save Our Student (SOS) tersebut perlunya suatu strategi komunikasi, dimana tingkat keberhasilan suatu tujuan akan tercapai seiring dengan bagaimana strategi komunikasi yang dilakukan dalam melaksanakan Program Save Our Student (SOS). Tujuan dilaksanakannya program tersebut, yaitu untuk menekan jumlah pelanggaran lalu lintas di kalangan pelajar dan mencegah terjadinya kecelakaan lalu lintas dengan fatalitas korban meninggal dunia akan tercapai.
\end{abstract}

Kata Kunci : Pelanggaran Lalu Lintas; Save Our Student (SOS); Strategi Komunikasi. 


\section{A. Pendahuluan}

Negara Republik Indonesia (POLRI) merupakan kepolisian nasional di Indonesia yang berperan sebagai alat negara dan mengemban tugas-tugas kepolisian di seluruh Indonesia yang diatur oleh peraturan perundang- undangan yang berlaku. Dalam melaksanakan tugas dan tanggung jawab serta wewenangnya tidaklah tanpa batas, melainkan harus berdasarkan hukum, sebagaimana dirumuskan dalam UU No. 2 Tahun 2002 tentang Kepolisian Negara Republik Indonesia. Dalam pelaksanaan fungsi dan tugas Polri yang diberi tanggungjawab dan wewenang yang pada hakekatnya berupa kekuasaan dalam bidang kepolisian untuk bertindak atau tidak bertindak apabila menemukan atau menghadapi suatu peristiwa baik itu berupa upaya pre-emtif, preventif, maupun represif.

Dewasa ini pembangunan nasional diselenggarakan secara menyeluruh,berencana, bertahap, dan berkesinambungan untuk menuju era pembangunan jangka panjang tahap ketiga. Pemeliharaan keamanan dalam negeri melalui penyelenggaraan fungsi kepolisian agar kegiatan pembangunan nasional berjalan efektif, efisien dan bersasaran maka diperlukan perencanaan pembangunan Kepolisian Negara Republik Indonesia melalui Grand Strategy Polri tahun 20052025. Grand Strategy dalam rangka memantapkan kemandirian Polri sebagaimana dirumuskan dalam buku biru Polri tentang reformasi Polri, Polri telah mencanangkan reformasi secara gradual yang meliputi reformasi instrumental, struktural dan kultural selama periode 2005-2025.

Grand Strategy Polri diharapkan dapat menjadi langkah dalam hal penguatan institusi yang berkelanjutan dari seluruh program dan kebijakan yang telah dikeluarkan selama ini. Secara keseluruhan Grand Strategy berkaitan dengan visi dan misi organisasi meliputi semua bidang dalam organisasi Polri. Sebagai upaya untuk melanjutkan reformasi birokrasi Polri sebagai salah satu program good goverment dari Negara yang saat ini telah dicanangkan melalui revitalisasi Polri, yang terdiri dari tiga pilar, yang merupakan rood map atau peta utama

Melihat situasi dan kondisi saat ini, khususnya di wilayah hukum Polres Blitar Kota, dimana Polres Blitar Kota memiliki 9 Polsek yang terdiri dari 4 polsek urban dan 5 polsek rural. Jumlah penduduk di wilayah Blitar Kota yaitu sekitar 558.255 jiwa. Masyarakat Kota Blitar dalam melakukan aktivitas sehari-hari menggunakan kendaraan bermotor dan didominasi oleh kendaraan sepeda motor.

Fenomena yang terjadi, banyak sekali pelajar khususnya pelajar Sekolah Menengah Pertama (SMP) maupun Sekolah Menengah Atas (SMA) atau Sekolah Menengah Kejuruan (SMK) yang belum cukup umur dan tidak memiliki SIM sudah mengendarai kendaraan sepeda motor pada 
saat akan pergi dan pulang sekolah. Ada bermacam-macam alasan kenapa pelajar tersebut mengemudi sendiri kendaraanya meskipun belum memiliki SIM. Alasan tersebut antara lain orang tua tidak memiliki waktu kalau harus mengantar dan menjemput anaknya pulang pergi dari rumah ke sekolah, biaya yang lebih mahal apabila harus pulang pergi ke sekolah dengan menggunakan angkutan umum, lalu jarak antara rumah dan sekolah yang terlalu jauh. Namun sebenarnya alasan itu tidaklah cukup kuat, karena hal tersebut justru menunjukkan sikap ketidakpedulian orang tua terhadap keselamatan putra- putrinya.

Selain itu, perilaku para pelajar sebagai pengguna jalan tersebut belum sesuai dengan safety riding atau cara berkendara yang benar dan aman. Mulai dari perilaku pengendara kendaraan bermotor yang kurang tertib, seperti banyak pengendara yang kurang memperhatikan marka jalan atau rambu-rambu lalu lintas, surat-surat kendaraan yang tidak lengkap seperti Surat Tanda Nomor Kendaraan (STNK) maupun Surat Izin Mengemudi (SIM).

Berdasarkan data Satuan Lalu Lintas Polres Blitar Kota tahun 2016, sebanyak 1.799 atau $15,9 \%$ pelajar yang melakukan pelanggaran lalu lintas, dan pada tahun 2017 dari bulan Januari sampai dengan bulan Maret sebanyak 438 atau 11,3\% pelajar yang melakukan pelanggaran lalu lintas. Selain pelanggaran juga terjadi 25 atau $15,1 \%$ kecelakaan lalu lintas yang melibatkan pelajar. Kecelakaan tersebut menyebabkan 68 pelajar menjadi korban. Dan pada tahun 2017 dari bulan Januari sampai dengan bulan Maret sebanyak 6 atau 12,5\% pelajar yang terlibat kecelakaan lalu lintas. Kecelakaan tersebut menyebabkan 21 pelajar menjadi korban.

Menurut data di atas, dapat diketahui bahwa angka pelanggaran lalu lintas di Kota Blitar banyak didominasi oleh kalangan pelajar baik itu pelajar Sekolah Menengah Pertama (SMP) maupun Sekolah Menengah Atas (SMA) atau Sekolah Menengah Kejuruan (SMK). Jenis pelanggaran tertinggi karena tidak memakai helm ketika berkendara, tidak memiliki Surat Ijin Mengemudi (SIM), berboncengan 3, dan pelanggaran marka maupun pelanggaran rambu- rambu lalu lintas. Oleh karena itu diberlakukanlah program Save Our Student (SOS) untuk menekan jumlah pelangaran lalu lintas pada pelajar. Sebelum diberlakukannya program Save Our Student (SOS) jumlah pelanggaran lalu lintas pada pelajar cukup tinggi di Kota Blitar.

Program Save Our Student (SOS) ini dibuat sebagai salah satu cara untuk mengurangi jumlah pelanggaran lalu lintas pada pelajar. Program ini pun bukanlah yang pertama kalinya dilaksanakan oleh Polisi Satuan Lalu Lintas Polres Blitar Kota, akan tetapi sudah dilaksanakan di beberapa tempat diantaranya wilayah Polrestabes Surabaya dan Polresta Sidoarjo. Namun, masih banyak kekurangan yang harus diperbaiki, mengingat masih adanya hambatan yang ditemui pada saat melaksanakan program tersebut.

Kegiatan yang dilaksanakan dalam program Save Our Student (SOS) yaitu melaksanakan koordinasi dan kerjasama dengan Pemerintah Kota Blitar, Dinas Perhubungan dan Dinas Pendidikan 
untuk terlaksananya tujuan dari program ini. Selain ini pihak kepolisian melaksanakan sosialisasi kepada pihak sekolah, orangtua, dan pelajar SMP dan SMA/SMK di Kota Blitar, serta pihak kepolisian melaksanakan penindakan tilang khususnya kepada para pelajar yang melakukan pelanggaran di jalan raya.

Program Save Our Student (SOS) merupakan program terbaru dari Satlantas Polres Blitar Kota yang bekerja sama dengan pihak sekolah baik Sekolah Menengah Pertama (SMP) maupun Sekolah Menengah Atas (SMA) atau Sekolah Menengah Kejuruan (SMK) di Kota Blitar. Program Save Our Student (SOS) merupakan program yang berdasar pada Undang-Undang Nomor 22 Tahun 2009 tentang Lalu Lintas dan Angkutan Jalan serta program Safety riding. Program Save Our Student ( $S O S$ ) bukan hanya program sesaat, namun program yang terus berkelanjutan sebagai upaya menekan jumlah pelanggaran lalu lintas pada pelajar, sehingga dapat membentuk karakter yang taat hukum pada para pemuda dan pemudi, sehingga dapat menciptakan publik muda yang baik di Kota Blitar.

Polisi Satuan Lalu Lintas Polres Blitar Kota dalam melaksanakan Program Save Our Student (SOS) tersebut perlunya suatu strategi komunikasi, dimana tingkat keberhasilan suatu tujuan akan tercapai seiring dengan bagaimana strategi komunikasi yang dilakukan dalam melaksanakan Program Save Our Student (SOS). Sehingga tujuan dilaksanakannya program tersebut, yaitu untuk menekan jumlah pelanggaran lalu lintas di kalangan pelajar dan mencegah terjadinya kecelakaan lalu lintas dengan fatalitas korban meninggal dunia akan tercapai.

Berdasarkan latar belakang di atas dilakukan penelitian ini tesis terkait "Strategi Komunikasi Satuan Lalu Lintas Polres Blitar Kota melalui Program Save Our Student (SOS) dalam Upaya Menekan Jumlah Pelanggaran Lalu Lintas Pada Pelajar”

\section{B. Metode}

Penelitian ini merupakan penelitian empiris yang menggunakan pendekatan kualitatif. Alasan menggunakan penelitian kualitatif ini karena dalam penelitian ini untuk memahami fenomena tentang apa yang dialami oleh subjek penelitian tentang strategi komunikasi yang digunakan oleh satuan lalu lintas Polres Blitar Kota pada program Save Our Student (SOS) dalam upaya menekan jumlah pelanggaran lalu lintas pada pelajar di wilayah hukum Polres Blitar Kota dengan cara deskripsi dalam bentuk katakata dan bahasa, pada suatu konteks khusus yang alamiah dan memanfaatkan berbagai metode alamiah. Beberapa konsep yang dikaji yaitu konsep strategi komunikasi, konsep pelanggaran lalu lintas, dan program Save Our Student (SOS), dengan metode ini, didapatkan gambaran nyata dari objek penelitian. 


\section{Pembahasan}

\section{Upaya Menekan Jumlah Pelanggaran Lalu Lintas Pada Pelajar Melalui Strategi Komunikasi Save Our Student (SOS)}

\subsection{Program Save Our Student (SOS)}

Program Save Our Student (SOS) adalah salah satu program yang dibuat oleh Satuan Lalu Lintas Polres Blitar Kota untuk menekan jumlah pelangaran lalu lintas pada pelajar dengan menekankan pemahaman tentang cara berlalu lintas yang baik dan benar untuk meningkatkan keselamatan diri sendiri maupun orang lain yang ditujukan khusus bagi para pelajar.

Program Save Our Student (SOS) dilaksanakan mulai dari tindakan pre-emtif, preventif dan represif. Tindakan pre-emtif yaitu melakukan upaya-upaya pencegahan secara dini sebelum pelanggaran terjadi, tindakan pre-emtif ini dapat dilakukan dengan cara menciptakan hubungan yang baik antar semua komponen, baik dengan pihak sekolah, pelajar, guru maupun para orangtua, sehingga akan meminimalisir terjadinya suatu tindak pelanggaran yang dilakukan oleh para pelajar. Kemudian melaksanakan kegiatan sosialisasi tentang safety riding kepada pelajar di sekolah mulai dari tingkat SD, SMP hingga SMA. Safety riding itu sendiri yakni bentuk pola perilaku untuk berkendara yang nyaman dan aman, baik untuk diri sendiri maupun pengguna jalan lain. Sehingga dengan mensosialisasikan program ini diharapkan agar pelajar dapat mengkondisikan diri dan mengerti bagaimana mengendarai sepeda motor yang aman dan nyaman. Selanjutnya barulah dilaksanakan tindakan-tindakan preventif.

Adapun tindakan preventif yaitu melakukan upaya-upaya pencegahan setelah melakukan tindakan pre-emtif. Tindakan ini dilakukan sebelum petugas Polri melakukan tindakan secara tegas, diantaranya melaksanakan tugas pengaturan, penjagaan, pengawalan dan patroli (Turjawali) di setiap pengal dan persimpangan jalan serta di daerah rawan pelanggaran dan kecelakaan. Sehingga dengan kehadiran polisi di jalan para pengguna khususnya pelajar akan lebih memiliki perhatian terhadap aturan lalu lintas Sedangkan tindakan represif dilakukan dengan melakukan tindakan tegas dilapangan, diantaranya melakukan penegakan hukum terhadap pelajar yang melakukan pelanggaran lalu lintas.

\subsection{Strategi komunikasi Save Our Student (SOS) dalam upaya menekan jumlah pelanggaran lalu lintas pada pelajar}

Strategi komunikasi yang digunakan oleh satuan lalu lintas Polres Blitar Kota melalui program Save Our Student (SOS) dalam upaya menekan jumlah pelanggaran lalu lintas pada pelajar. Menurut Rogers memberi batasan tentang pengertian strategi komunikasi yang menyatakan bahwa: 
“... strategi komunikasi sebagai suatu rancangan yang dibuat untuk mengubah tingkah laku manusia dalam skala lebih besar melalui transfer ide-ide baru. Strategi komunkasi memungkinkan suatu tindakan komunikasi dilakukan untuk target-target komunikasi yang dirancang sebagai target perubahan."1

Menurut Onong Uchjana Effendi dalam buku berjudul "Dimensi- dimensi Komunikasi" menyatakan bahwa :

“.... strategi komunikasi merupakan panduan dari perencanaan komunikasi (communication planning) dan manajemen (communications management) untuk mencapai suatu tujuan. Untuk mencapai tujuan tersebut strategi komunikasi harus dapat menunjukkan bagaimana operasionalnya secara taktis harus dilakukan, dalam arti kata bahwa pendekatan (approach) bisa berbeda sewaktu-waktu tergantung dari situasi dan kondisi”. ${ }^{2}$

Keberhasilan kegiatan komunikasi secara efektif banyak ditentukan oleh penentuan strategi komunikasi.

Beberapa teori komunikasi yang dikemukakan oleh para ahli, untuk strategi komunikasi yang memadai adalah teori dari seorang ilmuan politik dari Amerika Serikat yang bernama Harold D. Lasswell yang menyatakan bahwa:

“... cara yang terbaik untuk menerangkan kegiatan komunikasi atau cara untuk menggambarkan dengan tepat sebuah tindak komunikasi ialah menjawab pertanyaan "Who Says What In Which Channel To Whom With What Effect ? (siapa mengatakan apa dengan cara apa kepada siapa dengan efek bagaimana)." 3

Program Save Our Student (SOS) dilaksanakan oleh Satlantas Polres Blitar Kota dipimpin oleh Kasat Lantas Polres Blitar Kota AKP. Yanto Mulyanto, S.H., S.I.K dengan menggunakan strategi komunikasi dalam upaya menekan jumlah pelanggaran lalu lintas pada pelajar khususnya di wilayah hukum Polres Blitar Kota. Beberapa kegiatan dilakukan dalam program tersebut, mulai dari kegiatan pre-emtif, preventif sampai kegiatan represif yang ditujukan kepada para pelajar dilaksanakan di lingkungan sekolah dari tingkat Sekolah Dasar (SD), Sekolah Menengah Pertama (SMP), Sekolah Menengah Atas (SMA) atau Sekolah Menengah Kejuruan (SMK), para orang tua dan pihak sekolah.

Untuk mengetahui implementasi strategi komunikasi yang digunakan oleh satuan lalu lintas Polres Blitar Kota melalui program Save Our Student (SOS) dalam upaya menekan jumlah pelanggaran lalu lintas pada pelajar terlebih dahulu Satlantas Polres Blitar Kota menganalisa beberapa kegiatan yang dilaksanakan dan berpedoman pada strategi komunikasi yang ada, sehingga kegiatan tersebut dapat terlaksana sesuai dengan tujuan yang diharapkan.

Strategi komunikasi pada kegiatan tersebut yaitu dimulai dari pencarian fakta/masalah (fact finding), perencanaan (planning), pelaksanaan (actuating), hingga evaluasi (evaluating). 


\section{a. Pencarian fakta/masalah (fact finding)}

Merumuskan masalah merupakan langkah awal dari aktivitas Satlantas Polres Blitar Kota.

Pada tahap ini Satlantas Polres Blitar Kota mengidentifikasi, memantau, dan mengumpulkan fakta untuk mengetahui apa yang terjadi saat ini.

\footnotetext{
${ }^{1}$ Cangara, Hafied.. Pengantar Imu Komunikasi. Raja Graffindo Persada., Jakarta, 2013 h. 61

${ }^{2}$ Effendy, Onong Uchjana. Dimensi-dimensi Komunikasi, Alumni. Bandung 1981h.84

${ }^{3}$ Ibid.
} 


\section{b. Perencanaan (planning)}

Kegiatan yang dilakukan Satlantas Polres Blitar Kota yang kedua yaitu perencanaan (planning). Pada tahap perencanaan (planning), informasi yang sudah dikumpulkan pada tahap penemuan fakta

untuk membuat keputusan atau merumuskan bentuk kegiatan pada Program Save Our Student (SOS) yang akan dilakukan. Pada tahap ini juga dirumuskan anggaran untuk merealisasikan kegiatan tersebut.

c. Pelaksanaan (Actuating)

Kegiatan Satlantas Polres Blitar Kota yang ketiga yaitu

Pelaksanaan (Actuating). Pada tahap ini yang dilakukan oleh

Satlantas Polres Blitar Kota yaitu melaksanakan apa yang sudah

direncanakan pada tahap perencanaan untuk proses pencapaian tujuan pada program Save Our Student (SOS).

\section{d. Evaluasi (Evaluating)}

Tahap terakhir dalam kegiatan yang dilakukan Satlantas Polres

Blitar Kota yaitu tahap evaluasi (evaluating). Evaluasi merupakan suatu proses pengukuran dari hasil yang telah dicapai yang dilakukan sadar dan sengaja, yang dilakukan dengan rancangan pesan, sumber serta pemilihan saluran yang tepat untuk mencapai tujuan yang telah ditetapkan sebelumnya.

\section{Hambatan Pelaksanaan Strategi Komunikasi Melalui Program Save Our Student (SOS) Oleh Satuan Lalu Lintas Polres Blitar Kota}

\subsection{Hambatan pelaksanaan strategi komunikasi melalui program Save Our Student (SOS)}

Komunikasi merupakan proses yang rumit. Strategi komunikasi yang sudah matang pun tidak lepas dari faktor-faktor penghambat tersalurkannya pesan kepada komunikan. Cutlip ${ }^{4}$ menegaskan bahwa agar lebih mudah dalam melakukan dan mempraktikan strategi komunikasi, maka kita harus mengetahui langkah taktis strategi komunikasi supaya mencapai tujuan yang diinginkan. Tiga elemen hambatan yang ada untuk semua upaya komunikasi adalah sumber pengirim, pesan dan tujuan atau penerima. Kegagalan komunikasi dapat melibatkan satu atau lebih dari ketiga elemen ini.

Komunikasi yang efektif membutuhkan efisiensi disemua pihak diketiga elemen itu. Komunikator harus punya informasi yang memadai. Komunikator harus punya kredibilitas dimata penerima. Komunikator harus mampu menyampaikan informasi dengan cara yang dapat 
${ }^{4}$ Cutlip, Scott M. et. al. (2007). Effective Public Realtions, Edisi IX, cetakan ke-2. Jakarta : Kencana. h. 392-407. 
dipahami penerima. Komunikator harus menggunakan saluran yang akan menyampaikan pesan kepada penerima. Pesan harus sesuai kapasitas pemahaman penerima dan relevan dengan kepentingan atau kebutuhan penerima. Pesan harus memotivasi kepentingan penerima dan menimbulkan respon.

Selain itu faktor penghambat strategi komunikasi, antara lain :

a. Pembingkaian isi pesan, hal ini untuk mengetahui dari dekat pandangan komunikan mengenai masalah.

b. Mengetahui kebutuhan, kepentingan, dan perhatian dari komunikan sebagai sasaran. Komunikasi yang efektif harus didesain agar sesuai dengan situasi, waktu, tempat dan audien.

c. Bahasa yang senantiasa berubah, untuk itu dalam berkomunikasi

kita harus senantiasa memahami makna kata yang akan digunakan untuk menyampaikan pesan agar mudah dipahami.

d. Simbol Komunikasi, dalam berkomunikasi juga menggunakan simbol dan stereotip. Simbol menawarkan cara dramatis dan

langsung untuk berkomunikasi dengan banyak orang dijalur komunikasi yang panjang. Simbol telah dipakai sejak awal sejarah untuk memadatkan dan menyampaikan pesan yang kompleks.

Hambatan untuk menjelaskan pesan senantiasa ada dipihak komunikator dan komunikannya. Setiap orang tinggal didalam lingkungannya sendiri-sendiri. Lingkup lingkungan ini menyekat individu dari datangnya informasi yang tak ada hentinya dan semakin meningkat intensitasnya. Ada rintangan sosial, rintangan usia, rintangan bahasa atau kosakata, serta rintangan ekonomi dan politik. Ada rintangan ras; rintangan dan distorsi yang menutup komunikasi tampak jelas dalam perbedaan antar kelompok etnis dan ras di masyarakat Amerika yang multicultural. Sama halnya di Indonesia tentunya yang juga memeiliki keanekaragaman suku ras dan kepercayaan. Kemampuan atau kesediaan audien untuk menyerap pesan merupakan salah satu rintangan yang sering dilupakan. Terakhir, ada persaingan untuk mendapatkan perhatian orang di arena publik.

Dalam komunikasi, tak ada yang lebih menyulitkan ketimbang kenyataan bahwa kebanyakan audien media massa punya akses terbatas terhadap fakta. Dengan akses yang terbatas dan dengan beberapa informasi yang membingungkan ketimbang menjelaskan, orang sangat mengandalkan pada stereotip. Kesan spesifik dan signifikan menjadi sesuatu yang sangat umum atau digeneralisir. Ada orang yang tidak tau apa-apa tapi keras kepala. Orang-orang ini 
sulit diajak bicara, bahkan dengan informasi yang kuat sekalipun. Secara sederhana orang yang banyak mendapatkan informasi adalah orang-orang yang berminat pada informasi tersebut. Biasanya orang mencari informasi yang sesuai dengan sikap mereka dan menghindari informasi yang tidak sesuai dengan sikap mereka. Informasi tidak selalu merubah sikap, perubahan sikap dan perilaku setelah mendapat informasi pesan mungkin dipengaruhi pengalaman secara individual. Komunikasi harus diarahkan kepada sasaran yang tepat, bukan disebarkan kesegala arah agar hambatan semakin diminimalisir.

Pada kenyataan dilapangan masih ditemukan beberapa hambatan yang muncul dalam pelaksanaan strategi komunikasi yang digunakan oleh satuan lalu lintas Polres Blitar Kota melalui program Save Our Student (SOS) dalam upaya menekan jumlah pelanggaran lalu lintas pada pelajar. Namun demikian, pada hakikatnya kebanyakan dari gangguan yang timbul, bukan berasal dari sumber atau salurannya, tetapi dari audience (penerima)nya. Manusia sebagai komunikan memiliki kecenderungan untuk acuh tak acuh, meremehkan sesuatu, salah menafsirkan, atau tidak mampu mengingat dengan jelas apa yang diterimanya dari komunikator. Pada usia muda seperti para pelajar, mereka memiliki kecenderungan untuk mengekspos dirinya hanya kepada hal-hal yang dikehendakinya. Selain itu para pelajar memiliki kecenderungan berpikir stereotip, ketika anggota Satlantas Polres Blitar Kota melakukan sosialisasi di jalan raya mengenai program Save Our Student, pemikiran stereotip muncul dibenak para pelajar bahwa ketika polisi berkerumun di jalan raya berarti sedang melakukan razia kendaraan. Bagi para pelajar yang mengemudikan kendaraan dengan tidak membawa kelengkapan surat-surat kendaraan saat berkendara, tentu mereka akan berputar dan mencari jalan lain sehingga mereka tidak terpapar informasi dari kegiatan sosialisasi tersebut.

Pada kegiatan sosialisasi ke sekolah-sekolah yang ada di wilayah hukum Polres Blitar Kota, memiliki kekurangan dalam segi waktu dan efektifitas. Para pelajar hanya dihimbau untuk menaati peraturan lalu lintas tanpa ada paksaan yang mengikat sebagai bentuk pendewasaan pelajar dalam berkendara. Lagi-lagi pelajar dapat mengambil pilihannya pada apa-apa yang dikehendakinya tanpa mengindahankan himbauan- himbauan dari Satlantass Polres Blitar Kota.

\subsection{Solusi menekan pelanggaran lalu lintas pada pelajar melalui program Save}

\section{Our Student (SOS)}

Menjadi tanggung jawab Satlantas Polres Blitar Kota untuk mencari solusi terkait dengan hambatan-hambatan yang muncul di lapangan ketika melakukan strategi komunikasi program Save Our Student (SOS). Pendekatan secara persuasif dikedepankan untuk menjaring perhatian dari para pelajar di Kota Blitar. Perhatian ini sangat penting dalam menumbuhkan keinginan pada pelajar untuk mengetahui lebih lanjut mengenai aturan, lalu lintas, 
dan aturan lalu lintas. Sehingga diharapkan stereotip negatif mengenai polisi berkerumun di jalan raya akan hilang dan menjadi hal yang terlihat positif di mata pelajar dan memberikan ruang untuk ikut serta dan memiliki andil dalam setiap kegiatan sosialisasi di jalan raya.

Selain dari pihak kepolisian juga masih ada pihak lain yang juga

mendukung upaya program Save Our Student (SOS). Pihak-pihak tersebut antara lain pihak sekolah dan juga pihak keluarga. Selain dari pihak tersebut, dinas terkaitpun harus berperan serta dalam terlaksananya program Save Our Student (SOS) ini, diantaranya Pemerintah Kota Blitar (Pemkot Blitar), Dinas Perhubungan Kota Blitar (Dishub Kota Blitar) dan Dinas Pendidikan Kota Blitar (Disdik Kota Blitar).

Pada lingkup sekolah, Satlantas Polres Blitar Kota langsung merespon hambatan menjadi suatu ide yaitu mengumpulkan seluruh wali

murid untuk diberikan pemahaman mengenai dampak dan manfaat ketika berkendara sesuai aturan di jalan raya. Sehingga para orang tua yang notabene memiliki andil sangat besar dalam menentukan anaknya boleh berkendara di jalan raya atau tidak, memaksa anak untuk mengikuti aturan berlalu lintas. Karena apabila tidak menaati peraturan lalu lintas, anaknya tidak akan diperbolehkan membawa kendaraan ke jalan raya.

Polres Blitar Kota bekerja sama dengan pemerintah Kota Blitar untuk pengadaan fasilitas sepeda pancal gratis bagi seluruh siswa SMP dan SMA se Kota Blitar dan mewajibkan berangkat ke sekolah menggunakan sepeda tersebut. Hal ini diharapkan terwujudnya kota Blitar yang aman dan nyaman berlalu lintas, dan menekan resiko kecelakaan lalu lintas akibat kendaraan bermotor.

\section{Kesimpulan}

1. Strategi komunikasi satuan lalu lintas polres blitar kota melalui program

Save Our Student (SOS) dalam upaya menekan jumlah pelanggaran lalu lintas pada pelajar meliputi: sosialisasi yang dilakukan ke sekolah- sekolah di kota Blitar, pendidikan masyarakat secara umum melalui saluran komunikasi seperti radio dan media sosial seperti akun instagram satlantas Polres Blitar Kota, dan himbauan lalu lintas yang langsung dilakukan di jalan protokol pusat kota blitar yang sebagian besar telah efektif. Hal ini dapat dilihat dari realita yang ada, sekarang para pelajar sudah banyak yang telah mentaati peraturan, rambu-rambu lalu lintas, yang terukur pada menururnnya tindakan penilangan dan kecelakaan lalu lintas akibat tidak taat peraturan. Upaya Satlantas Polres Blitar Kota tidak hanya mengkomunikasikan kepada para pelajar mengenai tata tertib lalu lintas tetapi juga pentingnya mengutamakan keselamatan pada saat berkendara bagi para pelajar khususnya di Kota Blitar. 
2. Ada beberapa faktor pendukung dan penghambat dalam kegiatan komunikasi tersebut, yang menjadi faktor pendukungnya ialah

kendaraan operasional dinas yang digunakan, anggaran yang lancar, dan kerjasama tim personil gabungan yang berkoordinasi pada tiap-tiap pos penjagaan/zona yang telah ditentukan. Adapun faktor penghambatnya yakni manusianya (faktor mental disiplin yang kurang), alam (cuaca), dan insfrastruktur yang belum memadai.

\section{Bibliography}

\section{Buku}

Cangara, Hafied.. Pengantar Imu Komunikasi. Raja Graffindo Persada., Jakarta, 2013.

Cutlip, Scott M. et. al. (2007). Effective Public Realtions, Edisi IX, cetakan ke-2. Jakarta : Kencana.

Effendy, Onong Uchjana. Dimensi-dimensi Komunikasi, Alumni.

Bandung 1981 